\title{
Nasz Dom jako konstrukt społeczny
}

Gołąb, M., Sękowska, Z. (red.). (2019). Nasz Dom 1919-2019.

Pedagogiki społeczne, miasto i dzieciństwo w praktyce Naszego Domu. Bęc Zmiana.

\section{Abstrakt:}

Artykuł recenzyjny odnosi się do monografii Nasz Dom 1919-2019. Pedagogiki społeczne, miasto i dzieciństwo w praktyce Naszego Domu pod redakcją Marcina Gołąba oraz Zuzanny Sękowskiej (2019) i koncentruje się wokół problemu konstruktu społecznego, jakim jest dom. Celem tekstu jest pokazanie, jak w książce uchwycony został proces tworzenia się Naszego Domu zależnie od kontekstu, oraz omówienie tego, co opis o takiej charakterystyce może dać współczesnemu społeczeństwu. Autorka rozpoczyna artykuł od przybliżenia założeń konstruktywistów społecznych. Następnie odnosi się do głównych elementów wpływających na kształt, jaki przyjmuje konstrukt Naszego Domu: miejsca, pedagogiki społecznej, dzieci. W artykule pojawiają się odwołania do związku praktykowanego modelu wychowania z powstałym później paradygmatem studiów nad dzieciństwem. Szczególny nacisk położony jest na podmiotowość dziecka oraz proces tworzenia jego praw.

\section{Słowa kluczowe:}

dziecko, Janusz Korczak, konstruktywizm, Marcin Gołąb, Maryna Falska, Nasz Dom, podmiotowość, prawa dziecka, studia nad dzieckiem i dzieciństwem, Zuzanna Sękowska

* Aleksandra Zalewska-Królak - mgr, przygotowuje rozprawę doktorską w Instytucie Stosowanych Nauk Społecznych na Uniwersytecie Warszawskim dotyczącą głosu dziecka jako wyrazu jego podmiotowości. Kontakt: aleksandra.zalewska@uw.edu.pl. 


\section{Nasz Dom [Our Home] as a Social Construct}

Gołąb, M., \& Sękowska, Z. (Eds.). (2019). Nasz Dom 1919-2019. Pedagogiki

społeczne, miasto i dzieciństwo w praktyce Naszego Domu. Bęc Zmiana.

\section{Abstract:}

The review article refers to the monograph Nasz Dom 1919-2019. Pedagogiki społeczne, miasto i dzieciństwo w praktyce Naszego Domu [Our Home 1919-2019: Social Pedagogies, the City, and Childhood in the Practice of Our Home], edited by Marcin Gołąb and Zuzanna Sękowska (2019). It touches upon the problem of the social construct of what a 'home' can be. Its purpose is to show how the book captures the process of creating Nasz Dom [Our Home] depending on the context, and to discuss what a description of such characteristics can offer to the contemporary society. The author begins the article by presenting the assumptions of social constructivists. Then, she refers to the main elements influencing the shape of the structure of Our Home: the place, social pedagogy, and children. The article refers to the relationship between the practiced model of upbringing and the paradigm of childhood studies that emerged later. Particular emphasis is placed on the subjectivity of the child and the process of creating its rights.

\section{Key words:}

child, Janusz Korczak, constructivism, Marcin Gołąb, Maryna Falska, Nasz Dom [Our Home], subjectivity, children's rights, children's and childhood studies, Zuzanna Sękowska

\section{Wprowadzenie}

$\mathbf{N}$ asz Dom to nie tylko to placówka, która powstała 15 listopada 1919 roku w Pruszkowie; to nie wyłącznie Zakład Wychowawczy, którego kierownictwo polecono Marynie Falskiej, a opiekę lekarską Januszowi Korczakowi (Zespół do obsługi Placówek Opiekuńczo-Wychowawczych nr 2, 2021). Nasz Dom to także budynki ${ }^{1}$ zdeterminowane ograniczeniami i możliwościami architektonicznymi oraz osadzone w zdefiniowanej przestrzeni i kontekście historycznym; to dom rozumiany jako miejsce, z którego ktoś pochodzi; to koncepcja wychowania oraz proces tworzenia systemu, który umożliwia jej realizację; to idea uwzględniająca podmiotowość dzieci.

Książka Nasz Dom 1919-2019. Pedagogiki społeczne, miasto i dzieciństwo w praktyce Naszego Domu pod redakcją Marcina Gołąba i Zuzanny Sękowskiej

1 Odwołanie do budynków w Pruszkowie i na Bielanach, które były siedzibami Naszego Domu. 
$(2019)^{2}$ dotyka wszystkich wspomnianych elementów składających się na to, czym był i jest Nasz Dom. Publikacja, realizując postulat Petera L. Bergera i Thomasa Luckmanna (1966/2010), podejmuje się badań kulturowego kontekstu wiedzy i ukazuje życie codzienne, które dwóch wymienionych badaczy definiuje jako „interpretowaną przez ludzi rzeczywistość, z którą wiążą oni subiektywne znaczenia” (s. 32-33). Zgodnie z tą koncepcją każdy z nas ma do czynienia z rzeczywistością nazywaną „obiektywną”, niezależną od nas, oraz naszą świadomością, kształtowaną przez wzajemne oddziaływania $\mathrm{z}$ innymi oraz socjalizację. W takim rozumieniu społeczeństwo to zatem nieustający proces dialektyczny.

\section{Konstruktywizm społeczny}

Myśl Bergera i Luckmanna, która z założenia miała poruszać problematykę socjologii wiedzy, stała się punktem wyjścia m.in. dla konstruktywizmu. Konstruktywiści społeczni uważają, że nie można odizolować rzeczywistości od kontekstów oraz znaczeń. Świat, ich zdaniem, postrzegany jest w sposób subiektywny: ludzie poznają rzeczywistość kontekstualnie, poprzez pryzmat swoich doświadczeń i dominującej kultury; nadają jej określone znaczenia na podstawie zgromadzonych obserwacji. Potoczne sądy o rzeczywistości stają się „obiektywnymi” dowodami uzasadniającymi ich własną prawomocność w wyniku interakcji międzyludzkich (Giddens, 2009/2017, s. 274), jest ona zatem tworzona w procesie interpretacji. Cel badawczy konstruktywistów społecznych to dokumentacja oraz analiza procesów zgodnie z zasadą reifikacji. Ważne jest dla nich nie tylko to, jakie koncepcje rzeczywistości powstają i dlaczego, lecz także jak wygląda intersubiektywny proces ich konstruowania.

Publikacja Nasz Dom 1919-2019, którą w niniejszym artykule omawiam w zarysowanym wyżej kontekście, to zbiór różnorodnych perspektyw, odmiennych spojrzeń na konstrukt Naszego Domu. Celem, który postawili sobie autorzy i autorki monografii, jest uwspółcześnienie wybranych kwestii historycznych poprzez ukazanie kulturotwórczej roli miejsca. Zarys historii placówki, ze szczególnym uwzględnieniem zmiennych kontekstów wpływających na Nasz Dom, pokazuje przemiany społeczne, które zachodziły od 1919 do 2019 roku. Jest także próbą wytłumaczenia mitologii tej instytucji.

2 Książka jest w całości dostępna w internecie pod adresem https://issuu.com/beczmiana/ docs/nd_elektro_ok (pobrane 12 lipca 2021). 
W książce szczególną uwagę przypisuje się codzienności. Analiza zgromadzonych w archiwum Naszego Domu materiałów na ten temat pokazuje, że to, co uznawane za oczywiste, może być niezwykle ciekawym tropem badawczym, daje bowiem szansę na przybliżenie się do odpowiedzi na pytanie o istotę takich konstruktów jak dzieciństwo czy wychowanie, a tym samym dotyka także zagadnienia roli i formy placówek opiekuńczo-wychowawczych. Autorzy i autorki nie odpowiadają wprost na pytanie, czym jest Nasz Dom, nie przedstawiają także w sposób linearny jego historii. Starają się natomiast zrekonstruować konteksty, które miały wpływ na proces powstawania i funkcjonowania tej instytucji, ukazując ją tym samym jako konstrukt społeczny. Moim zdaniem, takie spojrzenie jest niezwykle inspirujące, $\mathrm{z}$ jednej strony pokazuje bowiem potencjał badawczy przyglądania się znaczeniom konstruktu, z drugiej zaś - pozwala wyciągać własne wnioski, otwiera nowe drogi poszukiwań. O wadze książki świadczą rezonujące ze sobą konteksty, które tworzą potencjalną całość. I właśnie w tej potencjalności tkwi klucz.

Marta Rakoczy, współautorka monografii, w materiale audiowizualnym Fundacji Bęc Zmiana (2019a) mówi, że jednym z celów książki było zbadanie, kto miał i co miało wpływ na proces negocjowania znaczeń, które tworzyły system pedagogiczny Naszego Domu, oraz które z wybranych schematów działań współtworzą lub będą współtworzyć nasze aktualne i przyszłe działania społeczne, polityczne i przede wszystkim edukacyjne. Podczas lektury publikacji starałam się dojść do odpowiedzi na pytanie, czy ten cel udało się zrealizować.

\section{Przenikające się miasto, pedagogiki społeczne i wizja dziecka tworzące Nasz Dom}

Monografia Nasz Dom 1919-2019 jest efektem pracy w ramach cyklu wydarzeń z okazji stulecia placówki powołanej przez Korczaka i Falską, którego kuratorką była Zuzanna Sękowska (Fundacja Bęc Zmiana, [2019c]), oraz stanowi podsumowanie inicjatyw składających się na projekt pod takim samym tytułem. Poszczególne rozdziały można czytać jako oddzielne całości, niemniej jednak składają się one na mozaikę kontekstów tworzących Nasz Dom. Wrażenie potęgują eseje wizualne oraz kończący książkę kolaż Nasz dom - w zgodzie z przyrodą Simone’a De Iacobisa i Małgorzaty Kuciewicz z grupy Centrala (2019, s. 238-239).

Autorzy i autorki publikacji działają w różnych instytucjach: Pracowni Studiów Miejskich w Instytucie Kultury Polskiej Uniwersytetu Warszawskiego (https://ikp.uw.edu.pl/instytut/struktura/pracownia-studiow-miejskich/), 
grupie projektowej Centrala (http://centrala.net.pl/), Korczakianum - pracowni Muzeum Warszawy (http://korczakianum.muzeumwarszawy.pl/), Fundacji Bęc Zmiana (https://beczmiana.pl/; wszystko pobrane 12 lipca 2021). Mają odmienne doświadczenia oraz spojrzenia na obserwowaną rzeczywistość. Dominuje wpływ perspektywy kulturoznawczej, ale w projekcie, przykładowo, brali także udział wspomniani wyżej artyści oraz Jaśmina Wójcik, pedagożka akademicka i przedszkolna, aktywistka. Książka jest również pełna różnorodnych form: od eseju wizualnego, poprzez teksty naukowe, spisane rozmowy, aż po wspomniany kolaż stworzony $\mathrm{z}$ archiwalnych zdjęć. Tematem łączącym pracę wszystkich osób jest Nasz Dom - znajdujący się w Warszawie, w specjalnie do tego celu stworzonym budynku na Bielanach - oraz codziennie kształtujące się w nim podejście pedagogiczne, zmieniające dominującą wizję dziecka. Monografia oddaje różnorodność perspektyw poprzez zwrócenie uwagi na poszczególne elementy wpływające na proces tworzenia się konstruktu Naszego Domu: architekturę, miasto, pedagogikę, dziecko.

Zgodnie z definicją ze Słownika języka polskiego PWN dom to m.in. „budynek”, „rodzina, domownicy” oraz/lub „miejsce, z którego ktoś pochodzi” („dom”, b.d.). Publikacja odnosi się do kontekstu każdego z elementów tej definicji. Nasz Dom ma swoje początki w Pruszkowie - był miejscem pobytu przede wszystkim dzieci z rodzin robotniczych. Jego historia jest bezpośrednio powiązana z miejscem, co wybrzmiewa w książce. Pruszków od XIX wieku był prężnie rozwijającą się osadą przemysłową, a od 1916 roku miastem. W pierwszych latach działalności Nasz Dom był finansowany z funduszy związków zawodowych. Z czasem ograniczona przestrzeń budynku stała się zauważalnym problemem: miała ona wpływ nie tylko na liczbę dzieci, które mogły przebywać w placówce, lecz także na ich funkcjonowanie oraz rozwój. Zmiana siedziby dała im zupełnie nowe szanse. Nie chodziło tylko o zajęcie większego terytorium; istotna była także okolica, w której miał powstać budynek o kształcie samolotu. Paradoks nowej przestrzeni doskonale oddaje wybrane przez Weronikę Parfianowicz (2019, s. 80) zdjęcie z archiwum przedstawiające Nasz Dom, nazywany "pałacem dzieci”, jako jedną z instytucji bielańskiego trójkąta („serka”). W swoim tekście autorka pokazuje szczególne umiejscowienie placówki, której zadaniem była pomoc dzieciom osieroconym lub pozbawionym opieki rodzicielskiej. Sąsiednie realizacje - Osiedle Zdobycz Robotnicza oraz teren wystawy Tani Dom Własny - miały być odpowiedzią na problem mieszkaniowy, z którym borykała się Warszawa. Z industrialnego Pruszkowa Nasz Dom przeniósł się na ówczesne obrzeża stolicy, przestrzeń zieloną i pustą, ale jednocześnie otwartą na innowacyjne myślenie. Bielany uznawane były wówczas za przedłużenie Żoliborza, realizację utopijnej wizji 
urbanistyczno-architektonicznej (Piotrowski, 2019, s. 71). Nowy gmach Naszego Domu miał być „maszyną” do spełniania marzeń, eksperymentem architektonicznym, który sprawiłby, że budynek byłby dwa kroki przed wychowankiem (Fundacja Bęc Zmiana, 2019b). W publikacji wyraźnie wybrzmiewa teza, że założenia urbanistyczno-architektoniczne wpływają na kształtujący się w Naszym Domu model wychowania.

Istotną część książki zajmują także odniesienia do procesu tworzenia się myśli pedagogicznej Falskiej i Korczaka. Publikacja przywraca Falską do dyskursu - skupionego zazwyczaj głównie na pedagogu - i pokazuje, jak odmienna definicja domu przyjmowana przez te dwie osoby miała wpływ na zakres działalności Naszego Domu. Falska, dostrzegając potencjał dużej przestrzeni, chciała otwierać się na społeczność lokalną. Korczak natomiast był raczej za wizją domu bardziej zamkniętego, skupiającego się głównie na wychowankach. Myśl Falskiej była bliska współczesnej idei domów sąsiedzkich, Korczakowska zaś szła w stronę tworzenia rodzin zastępczych dających poczucie stabilności, posiadania rodziny. Niemniej jednak oboje dążyli do tego, żeby Nasz Dom był miejscem, w którym mógł realizować się proces samowychowywania (Gołąb, Rakoczy, Sękowska, 2019, s. 24). Warto podkreślić, że ten proces dotyczył nie tylko dzieci, lecz także dorosłych.

Problematyka wychowania obywatela, na której skupiają się autorzy i autorki książki, jest ciekawym zagadnieniem. Otwartość (lub jej brak) na społeczność lokalną ma wpływ na rozwój jednostki w poczuciu inkluzywności (albo ekskluzywności). Zgodnie z myślą pedagogiczną dominującą w Naszym Domu wychowawca odpowiada przed dziećmi za społeczeństwo (Rakoczy, 2019, s. 165). Celem działań placówki było dbanie o ład społeczny, co Marta Ciesielska tłumaczy, przytaczając system sprawiedliwości panujący w Naszym Domu ([Świątkowska], 2019, s. 144). Asymetria władzy dorosłych i dzieci była intencjonalnie minimalizowana, a dziecko traktowano podmiotowo, jako partnera w relacji. Nie mówiło się o jego „urabianiu”, czemu przeciwni byli zarówno Falska, jak i Korczak. Nacisk na samowychowanie oraz samoorganizację pokazują stojącą za takim podejściem wizję dziecka - aktywnego współtwórcy rzeczywistości społecznej.

Na tym właśnie obrazie dziecka zbudowany został interdyscyplinarny paradygmat studiów nad dzieciństwem, którego początki datowane są na przełom lat 80. i 90. XX wieku (Brzozowska-Brywczyńska, 2014; Hammersley, 2017; Mayall, 2013; Radkowska-Walkowicz, Reimann, 2018; Thomas, 2017). Perspektywa ta zakłada, że dzieciństwo to konstrukt społeczny, a zatem jest zmienne (James, Prout, 1997). Dziecko jest zaś aktorem i podmiotem społecznym (Hammersley, 2017; Prout, James, 1990). Takie podejście sprawia, że dziecięca 
wiedza (Mayall, 2008) staje się istotną daną naukową. Dzieci nie są traktowane jako przyszli dorośli, postrzega je się raczej w kontekście „bycia”, niż „stawania się" [as 'beings' rather than 'becomings'] (Gallacher, Gallagher, 2008, s. 502). Jak mówił Korczak, przywołując tezę o ich pełnowartościowości jako obywateli, „nie ma dzieci - są ludzie” (Smolińska-Theiss, 2013, s. 15). W publikacji autorzy odnoszą się do tej perspektywy - na przykładzie praktyki pedagogicznej ukazują potencjał dziecięcości, która wcale nie jest tożsama z niedojrzałością ([Świątkowska], 2019, s. 146). Korczakowska wizja dziecka nie tyle zrównywała dziecko z dorosłym, ile podkreślała równoważność istoty możliwości działania sprawczego tych dwóch podmiotów.

Niewątpliwie przełomowym wydarzeniem historycznym, które miało wpływ na proces włączania dzieci do badań społecznych, było stworzenie Konwencji o Prawach Dziecka (Broström, 2012). Uregulowania prawne umożliwiły prowadzenie badań $\mathrm{z}$ dzieckiem $\mathrm{w}$ bezpieczny sposób i z poszanowaniem jego podmiotowości (Thomas, O’Kane, 1998). Prawa nie powinny być jednak nigdy ustanawiane odgórnie i na stałe: jeśli zakładamy, że świat jest zmienny, to prawa również powinny umożliwiać ich modyfikację. Refleksyjne podejście do tematu, stałe zadawanie pytań, kwestionowanie zastałych norm oraz - przede wszystkim - otwartość na włączanie w te procesy dzieci są szansą dla aktualnego w danym momencie rozumienia dzieciństwa. Ten wątek pojawia się w recenzowanej książce. Kodeks Sądu Koleżeńskiego stworzony przez Korczaka był tylko punktem odniesienia, bazą otwartą na modelowanie. Jak wskazuje Ciesielska ([Świątkowska], 2019, s. 149), w Naszym Domu pracowano nad jego treścią i nie traktowano go jako dokumentu niepodlegającego nowelizacjom. Poczucie wpływu na kształt zasad obowiązujących w miejscu, w którym spędzało się większość czasu, sprawiało, że łatwiej było czuć się odpowiedzialnym za ich przestrzeganie, czego dowodem są dokumenty zachowane $\mathrm{w}$ archiwach Korczakianum. Ta kwestia jest szczególnie istotna w świetle pojawiającej się obecnie możliwości wprowadzenia zmian w europejskiej strategii dotyczącej praw dziecka ${ }^{3}$.

W recenzowanej publikacji wybrzmiewa wiele praw dzieci, współcześnie wchodzących w skład Konwencji o Prawach Dziecka: prawo do zabawy, prawo do tożsamości, prawo do nauki, prawo do głosu, prawo do zrzeszania się. Nie jest to przypadkowa zbieżność. Wnioski z praktyki pedagogicznej Falskiej i Korczaka były bowiem podstawą to stworzenia praw dziecka (Smolińska-Theiss, 2013). Jak zauważa Barbara Młodziejewska (Fundacja Bęc Zmiana, 2019a),

3 Więcej na temat konsultacji uwzględniających aktywny udział dzieci znaleźć można na stronie internetowej Komisji Europejskiej (b.d.). 
to, co kiedyś było alternatywne, dziś jest normą (niestety, trzeba uściślić, że czasem wyłącznie deklaratywną, bo zmiany dotyczące praktyk wciąż poddawane są pod dyskusję $)$. Przykładem działań, które można uznać za prekursorskie, były codzienne zmagania pedagogów Naszego Domu, szczegółowo opisane w monografii oraz opatrzone komentarzami wskazującymi na refleksyjność ich twórców. Myślę, że jest to głos nadziei także w odniesieniu do manifestu Wójcik ([2019]) dotyczącego edukacji alternatywnej - może w przyszłości wybór modelu edukacji zgodnego z potrzebami danego dziecka stanie się normą. W publikacji pojawia się dokumentacja fotograficzna warsztatów przeprowadzonych przez aktywistkę z dziećmi z Naszego Domu (Wójcik, Wróblewski, 2019, s. 229-236),, ale mnie brakuje omówienia treści albo chociaż odniesienia do wspomnianego wyżej tekstu dotyczącego poży tków łączenia praktyk edukacyjnych z pracami artystycznymi. Autorka podkreśla w nim rolę relacji dziecka i dorosłego w procesie edukacji oraz podaje przykłady osobistych doświadczeń, które wskazały jej drogę pedagogiczną. Zagrożenia pruskiego modelu edukacji, które wymienia, nawiązują do opisanego przez Michaela Foucaulta (1975/2020) wykorzystywania autorytetu pedagogicznego oraz traktowania edukacji jako funkcji instytucji totalnej - szkoły (Goffman, 1961/2011). Tylko zaufanie do dziecka i wiara w dziecięce możliwości umożliwia mu autonomię i sprawczość. Ta idea była widoczna w codziennej praktyce Falskiej i Korczaka oraz w jego publikacjach („Zaufanie do dziecka to prolog do myślenia korczakowskiego” [Świątkowska], 2019, s. 146). Niestety jesteśmy jeszcze na etapie wprowadzania tego podejścia w życie, ale już sama jego obecność w dyskursie jest istotnym krokiem ku zmianie.

Warto poruszyć jeszcze jedną kwestię. „Dziecko podobnie jak dorosły nie mówi jedynie o czymś, lecz mówi do kogoś, dla kogoś, ze względu na coś" (Rakoczy, 2019, s. 173), a owo „coś” jest zawsze związane z kontekstem sytuacyjnym. Archiwum (tu - archiwum Naszego Domu) zbierające różnorodne materiały umożliwia próbę rekonstrukcji kontekstu. Istotny jest jednak także sam kontekst tworzenia owych materiałów. Falska pilnowała tego, żeby w kalendarzu zapiski dzieci były notowane bez zmian (np. poprawek). Dodawała jednak do tych danych swoje adnotacje, przemyślenia, interpretacje, wyraźnie zaznaczając, kto jest autorem danego fragmentu. Są to informacje na marginesie, ukazujące tło, osobistą perspektywę, ale niewkraczające w autonomię wypowiedzi dziecka; mają jednak duże znaczenie, ponieważ zakreślają szerszy kontekst. Przykładem może być przytoczona w publikacji forma opowieści

4 Więcej na ten temat można przeczytać w Raporcie Alternatywnym (ATD Czwarty Świat i in., 2020). 
o zabawach - dzieci podkreślają brak niebezpieczeństwa wybranej formy rozrywki, ponieważ wiedzą, że jest to istotne dla Maryny. Proces notowania poznajemy szczegółowo dzięki temu, że Falska opisuje całą procedurę oraz jej założenia (Rakoczy, 2019, s. 167). Wskazuje przykładowo, że na wypowiedzi dzieci nie reagowała nawet mimiką, pisała jak automat (s. 168). Rakoczy zwraca w swoim tekście uwagę na ówczesną rolę słowa pisanego (s. 166) oraz znaczenie dyktowania w odniesieniu do podziału władzy (s. 174).

\section{Zakończenie}

Omawiana publikacja ukazuje niezwykle istotną rolę archiwum dla procesu rekonstrukcji kontekstów, które składają się na omawiany konstrukt. Kolaż zamykający monografię symbolicznie to podkreśla, wskazując na rolę różnych elementów i perspektyw na kształtowanie się całościowej wizji. Cytując Gołąba (2019), Nasz Dom „był po prostu domem” (s. 207), stałym miejscem na mapie Warszawy, do którego zawsze można była powrócić. Na jego kształt miała wpływ zmieniająca się rzeczywistość społeczna, a w szczególności polityczna, zawsze jednak był domem - budynkiem o określonym kształcie, składającym się ze stałych domowników, a w pewnym momencie także tymczasowych gości (społeczność lokalna); był również miejscem, które tworzyło tożsamość zbiorową i dawało poczucie przynależności. Autorom i autorkom książki Nasz Dom 1919-2019 udało się oddać mitologię tego miejsca oraz ukazać je jako inspirację do poszukiwań nowych rozwiązań sytuacji współczesnych dzieci. Monografia pokazuje, jak odkrywać doświadczenia oraz znaczenia poprzez podążanie za opisem życia codziennego rozumianego jako kontinuum typizacji (Berger, Luckmann, 1966/2010, s. 50). Ciekawym zagadnieniem, które pojawia się $\mathrm{w}$ tym kontekście, jest badanie procesu projektowania dzieciństwa oraz tego, jak wpływa on na kształt - przykładowo - edukacji. Szczególny charakter zbiorów archiwalnych, w których wybrzmiewa głos najmłodszych, ukazuje także rolę języka. Jak podkreślają Berger i Luckmann, „jest [on] zdolny stać się obiektywną przechowalnią olbrzymich zbiorów znaczeń i doświadczeń, które można zachować w czasie i przekazywać kolejnym pokoleniom" (s. 55). Znak $\mathrm{w}$ tym rozumieniu dostarcza informacji na temat subiektywnych czynników wpływających na proces jego powstania oraz związanych z nimi praktykami społecznymi (s. 53). Dlatego tak ważny jest postulat studiów nad dzieciństwem - zbieranie doświadczeń dzieci i traktowanie ich jako wiedzy na temat rzeczywistości społecznej. 


\section{Bibliografia}

ATD Czwarty Świat i in. (2020). Raport Alternatywny. UNICEF. Pobrane 2 października $2020 \mathrm{z}$ : https://unicef.pl/content/download/44921/file/RAPORT\%20ALTERNATYWNY\%20WERSJA\%20POLSKA.pdf.

Berger, P. L., Luckmann, T. (2010). Społeczne tworzenie rzeczywistości. Traktat z socjologii wiedzy (J. Niżnik, tłum.). WN PWN. (wyd. oryg. 1966).

Broström, S. (2012). Children's participation in research. International Journal of Early Years Education, 20(3), 257-269. https://doi.org/10.1080/09669760.2012.715407.

Brzozowska-Brywczyńska, M. (2014). Dziecięce obywatelstwo. Kilka refleksji na marginesie idei dziecięcej partycypacji. Acta Universitatis Lodziensis. Folia Sociologica, 49, 11-27.

Centrala (Kuciewicz, M., De Iacobis, S.). (2019). Nasz Dom - w zgodzie z przyrodą. Kolaż. W: M. Gołąb, Z. Sękowska (red.), Nasz Dom 1919-2019. Pedagogiki społeczne, miasto i dzieciństwo w praktyce Naszego Domu (s. 137-139). Bęc Zmiana.

dom. (b.d.). Słownik języka polskiego PWN. Pobrane 20 września 2020 z: https://sjp. pwn.pl/sjp/dom;2453213.html.

Foucault, M. (2020). Nadzorować i karać. Narodziny więzienia (T. Komendant, tłum.). Aletheia. (wyd. oryg. 1975).

Fundacja Bęc Zmiana (2019a, 24 grudnia). Nasz Dom 1919-2019. Vimeo. Pobrane 1 października $2020 \mathrm{z}$ : https://vimeo.com/381331503.

Fundacja Bęc Zmiana (2019b, 24 grudnia). Nasz Dom / Budynek. Vimeo. Pobrane 1 października $2020 \mathrm{z}$ : https://vimeo.com/381332880.

Fundacja Bęc Zmiana ([2019c]). Nasz Dom 1919-2019. Cykl wydarzeń w stulecie placówki wychowawczej powołanej przez Marynę Falska i Janusza Korczaka. Pobrane 1 października $2020 \mathrm{z}$ : https://beczmiana.pl/naszdom/.

Gallacher, L.-A., Gallagher, M. (2008). Methodological immaturity in childhood research? Thinking through 'participatory methods'. Childhood, 15(4), 499-516. https://doi.org/10.1177/0907568208091672.

Giddens, A. (2017). Socjologia. Wydanie nowe (P. W. Sutton, współpr., O. Siara, A. Szulżycka, P. Tomanek, tłum.). WN PWN. (wyd. oryg. 2009).

Goffman, E. (2011). Instytucje totalne. O pacjentach szpitali psychiatrycznych i mieszkańcach innych instytucji totalnych (O. Waśkiewicz, J. Łaszcz, tłum.). Gdańskie Wydawnictwo Psychologiczne. (wyd. oryg. 1961).

Gołąb, M. (2019). „Znałem imię każdego psa, a było ich wtedy w Domu nie mniej niż nas”. Powojenne losy Ośrodka Wychowawczego RTPD „Nasz Dom” im. M. Falskiej oraz Domu Młodzieży im. F. Dzierżyńskiego. W: M. Gołąb, Z. Sękowska (red.), Nasz Dom 1919-2019. Pedagogiki społeczne, miasto i dzieciństwo w praktyce Naszego Domu (s. 197-207). Bęc Zmiana.

Gołąb, M., Rakoczy, M., Sękowska, Z. (2019). Nasz Tom. Pedagogiki społeczne, miasto i dzieciństwo w praktyce Naszego Domu. W: M. Gołąb, Z. Sękowska (red.), Nasz 
Dom 1919-2019. Pedagogiki społeczne, miasto i dzieciństwo w praktyce Naszego Domu (s. 18-35). Bęc Zmiana.

Gołąb, M., Sękowska, Z. (red.). (2019). Nasz Dom 1919-2019. Pedagogiki społeczne, miasto i dzieciństwo w praktyce Naszego Domu. Bęc Zmiana.

Hammersley, M. (2017). Childhood Studies: A sustainable paradigm?. Childhood, 24(1), 113-127. https://doi.org/10.1177/0907568216631399.

James, A., Prout, A. (1997). Constructing and reconstructing childhood: Contemporary issues in the sociological study of childhood. Routledge.

Komisja Europejska. (b.d.). Strategia UE na rzecz praw dziecka (2021-2024). Pobrane 20 września $2020 \mathrm{z:}$ https://ec.europa.eu/info/law/better-regulation/have-your-say/initiatives/12454-Delivering-for-children-an-EU-strategy-on-the-rights-ofthechild/public-consultation_pl.

Mayall, B. (2008). Conversations with children: Working with generational issues. W: P. Christensen, A. James (red.), Research with children: Perspectives and practices (s. 109-124). Routledge.

Mayall, B. (2013). A history of the sociology of childhood. UCL IOE Press.

Parfianowicz, D. (2019). Nasz Tani Dom Własny?. W: M. Gołąb, Z. Sękowska (red.), Nasz Dom 1919-2019. Pedagogiki społeczne, miasto i dzieciństwo w praktyce Naszego Domu (s. 81-96). Bęc Zmiana.

Piotrowski, I. (2019). Poszukiwanie przestrzeni. Wśród choin na piasku. W: M. Gołąb, Z. Sękowska (red.), Nasz Dom 1919-2019. Pedagogiki społeczne, miasto i dzieciństwo w praktyce Naszego Domu (s. 70-80). Bęc Zmiana.

Radkowska-Walkowicz, M., Reimann, M. (red.). (2018). Dzieci i zdrowie. Wstęp do childhood studies. Oficyna Naukowa.

Rakoczy, M. (2019). „Dwa sny chcę podać” - Leonard dyktuje kalendarz Naszego Domu. W: M. Gołąb, Z. Sękowska (red.), Nasz Dom 1919-2019. Pedagogiki społeczne, miasto i dzieciństwo w praktyce Naszego Domu (s. 160-183). Bęc Zmiana.

Smolińska-Theiss, B. (red.). (2013). Rok Janusza Korczaka 2012. Nie ma dzieci - sa ludzie. Biuro Rzecznika Praw Dziecka.

[Świątkowska, B.]. (2019). „Zaufać dopiero wkraczającemu w świat”. Rozmowa z Martą Ciesielską o aktualności myśli Marii Falskiej i Janusza Korczaka. W: M. Gołąb, Z. Sękowska (red.), Nasz Dom 1919-2019. Pedagogiki społeczne, miasto i dzieciństwo w praktyce Naszego Domu (s. 144-159). Bęc Zmiana.

Thomas, N. (2017). Turning the tables: Children as researchers. W: P. Christensen, A. James (red.), Research with children: Perspectives and practices (wyd. 3, s. 160179). Routledge.

Thomas, N., O'Kane, C. (1998). The ethics of participatory research with children. Children and Society, 12(5), 336-348. https://doi.org/10.1111/j.1099-0860.1998. tb00090.x. 
[Wójcik, J.]. ([2019]). Manifest edukacji alternatywnej. Jaśmina Wójcik o pożytkach łączenia praktyk edukacyjnych z pracami artystycznymi. Bęc Zmiana. Pobrane 20 września $2020 \mathrm{z}$ : https://beczmiana.pl/manifest-edukacji-alternatywnej/.

Wójcik, J., Wróblewski, J. (2019). Dokumentacja fotograficzna warsztatów Jaśminy Wójcik i pochodu ze sztandarami. W: M. Gołąb, Z. Sękowska (red.), Nasz Dom 1919-2019. Pedagogiki społeczne, miasto i dzieciństwo w praktyce Naszego Domu (s. 144-236). Bęc Zmiana.

Zespół do obsługi Placówek Opiekuńczo-Wychowawczych nr 2. (2021). Historia Domu Dziecka nr 1 "Nasz Dom” im. Maryny Falskiej na Bielanach, 1919-2018. Pobrane 10 stycznia 2021 z: https://www.zpow2.pl/placowki/dom-dziecka-nr-1/historia. 